\title{
Dicotomia: visão de ação humana em Deus
}

\author{
Dichotomy: view of human action in God \\ Dicotomía: visión de la acción humana en Dios
}

Recebido: 17/11/2021 | Revisado: 22/11/2021 | Aceito: 23/11/2021 | Publicado: 03/12/2021

\author{
Odirlei Arcangelo Lovo \\ ORCID: https://orcid.org/0000-0003-0576-9284 \\ Universidade Federal de Rondônia, Brasil \\ E-mail: oalovo@gmail.com \\ Mário Antônio Sanches \\ ORCID: https://orcid.org/0000-0002-5794-2272 \\ Pontifícia Universidade Católica do Paraná, Brasil \\ E-mail: m.sanches@pucpr.br
}

\begin{abstract}
Resumo
Neste artigo se fomenta a necessidade de superar a dicotomia entre o agir humano e o agir de Deus. Indaga-se: como promover o espírito de amor, unidade e vivência fraterna? O método é narrativo-bibliográfico, e o objetivo é superar a dicotomia e assumir a unidade de amor é reconhecer que o ser humano, criado do húmus da terra ao som da voz de Deus, é capaz de sentir as necessidades e possibilidades, ao mesmo tempo, capaz de ouvir a voz do Espírito. Elucidase a essência administrativa, que é práxis, fomentando a unidade e o agir humano na narrativa de que o ser humano é administrador e cocriador da obra de Deus. Expectar o futuro é possibilidade, é necessidade e se realiza na esponsalidade com o Criador. Se faz fundamental a formação da consciência da pessoa, para que se possa, mediante o agir humano, administrar a Criação de Deus.
\end{abstract}

Palavras-chave: Ação humana; Esponsalidade; Essência administrativa; Cocriação.

\begin{abstract}
This article promotes the need to overcome the dichotomy between human action and God's action. The question is: how to promote the spirit of love, unity and fraternal life? The method is narrative-bibliographic, and the objective is to overcome the dichotomy and assume the unity of love is to recognize that the human being, created from the humus of the earth to the sound of God's voice, is able to feel the needs and possibilities, at the same time, able to hear the voice of the Spirit. The administrative essence is elucidated, which is praxis, fostering unity and human action in the narrative that human beings are administrators and co-creators of God's work. Expecting the future is a possibility, it is a necessity, and it takes place in spousalty with the Creator. The formation of a person's conscience is fundamental, so that it is possible, through human action, to manage God's Creation.
\end{abstract}

Keywords: Humanaction; Spousality; Administrative essence; Co-creation.

\section{Resumen}

Este artículo promueve la necesidad de superar la dicotomía entre la acción humana y la acción de Dios. La pregunta es: ¿cómo promover el espíritu de amor, unidad y vida fraterna? El método es narrativo-bibliográfico, y el objetivo es superar la dicotomía y asumir que la unidad del amor es reconocer que el ser humano, creado a partir del humus de la tierra al sonido de la voz de Dios, es capaz de sentir las necesidades y posibilidades, al mismo tiempo, poder escuchar la voz del Espíritu. Se dilucida la esencia administrativa, que es la praxis, fomentando la unidad y la acción humana en la narrativa de que los seres humanos son administradores y co-creadores de la obra de Dios. Esperar el futuro es una posibilidad, es una necesidad y tiene lugar en unión conyugal con el Creador. La formación de la conciencia de la persona es fundamental para que sea posible, a través de la acción humana, gestionar la Creación de Dios.

Palabras clave: Accion humana; Spousality; Esencia administrativa; Co-creación.

\section{Introdução}

A pessoa cristã vive hodiernamente a complexidade de compreender a existência humana sob a perspectiva da presença de Deus conosco. O Cristianismo marcou a cultura ocidental ao longo dos séculos. As pessoas nascem e crescem em sociedades ditas como cristãs e nem sempre mantém viva a mensagem cristã de um Deus que age na história e na vida pessoal de cada um. 
Assim, o Cristianismo se institucionaliza em Igrejas e a pertença às Igrejas é transformada em formalidades, cumprimentos de rituais e seguimento de normas comunitárias. Desse modo, a compreensão da ação humana simultaneamente como ação de Deus no mundo se perde e o administrar da vida em sociedade é relegado a uma dimensão alheia à fé. Percebese, nesse contexto, uma perspectiva mecânica, impregnada pelo pragmatismo inconsequente usualmente contrário à mensagem do Reino de Deus, presente em cada pessoa.

A Teologia cristã precisa reagir e inspirar à Religião para que sejam mais que uma expressão formal e ritualizada, sem impacto no cotidiano e sem deixar marcas no modo como cada pessoa cristã administra a vida pessoal, familiar, comunitária e social. Deste modo, este artigo objetiva explicitar ao ser humano que há um chamado divino para administrar a obra de Deus, de onde nasce a essência administrativa humana que impulsiona a uma ação no mundo marcadamente humano-divina, refletindo, portanto, à imagem e semelhança de Deus, Segundo Lovo,

O ser humano sempre se des-envolve, mediante a essência administrativa e se torna ato administrativo de Deus na criação. Enseja-se que a esperança é constitutiva da ação necessária em perspectiva do reino esperançado, é preciso compreender que "a interpretação correta do conceito de ser humano como senhor do universo é entendê-lo no sentido de administrador responsável ${ }^{\prime \prime}$ (Lovo, 2020, p. 23).

Compreender a Palavra de Deus que habita o íntimo de cada pessoa propulsa a capacidade de ouvir a Palavra, a Vontade e o Amor de Deus; ato que eleva o ser humano a compreender-se e viver o Espírito que habita o íntimo humano. Quando se enfatiza a essência administrativa como um Si de Deus que habita o íntimo humano, quer-se pontuar que, "no fundo é o próprio Deus que oferece ao homem a honra de cooperar com todas as forças da inteligência na obra da criação" (João Paulo II, 2004, n 460).

$\mathrm{O}$ ser humano é criado à imagem e semelhança de Deus. O agir humano e o agir de Deus se apresentam enquanto um projeto único, de amor e de cuidado. Todavia, o individualismo e a dicotomia entre o agir humano e o agir de Deus, faz com que se rejeite a obra de Deus no ser humano, mesmo sendo à Sua imagem e semelhança. É necessário superar a crise de sentido e o individualismo pragmático e dicotomizante, que não permite ver o agir humano, como fonte de amor, cuidado e ternura de Deus!

O ser humano tem consciência de que "a crise torna-se ocasião de discernimento e elaboração de nova planificação. Com esta chave, feita mais de confiança que resignação, convém enfrentar as dificuldades da hora atual" (Bento XVI, 2009, $\mathrm{n}^{\circ}$ 21). É prudente afirmar que, a pessoa não vive duas vidas paralelas "por um lado, a vida chamada 'espiritual', com os seus valores e exigências, e, por outro, a chamada vida 'secular', ou seja, a vida da família, do trabalho, das relações sociais, do empenhamento político e da cultura" (João Paulo II, 2004, nº 546).

Novamente se chama a atenção para o desprendimento da pessoa em relação às realidades que precisam ser administradas. Na dicotomia da ação humana e o agir de Deus, a pessoa deixa de realizar aquilo que é necessário e possível. Neste sentido, a essência administrativa possibilita o ser humano a realizar sua própria missão de ser um ato que reluz à imagem e semelhança de Deus, isto é, a alegria de servir a Deus revelando a humanidade ao ser humano.

O ser humano é chamado à responsabilidade sob a qual se constitui o livre-arbítrio. Negar a responsabilidade é negar e agir contra o livre-arbítrio. Quando se diz que o agir de cada pessoa reluz à imagem e semelhança de Deus, se pontua que a pessoa é um "ser apto a tomar decisões conscientes e autocríticas, agir com base nestas decisões e assumir responsabilidades por elas - estas são as características das quais é composta a imagem de Deus em nós” (Hefner, 1987, p. 328).

${ }^{1}$ Francisco, 2015, $\mathrm{n}^{\mathrm{o}} 116$ 
O ser humano, em livre-arbítrio, vive a práxis de vida e de vivência que possibilita administrar e cocriar o Reino de Deus. Não se pode reduzir a presença de Deus conosco ao conjunto estéril de ritos e rezas. O ser humano ao ouvir a Palavra de Deus realiza uma co-oração e participa do mistério onde Deus realiza sua Palavra que diz "dar-vos-ei coração novo, porei no vosso íntimo espírito novo, tirarei do vosso peito o coração de pedra e vos darei um coração de carne" (Ez 36, 26).

A ciência, a potência e a presença humana, versam sobre o propósito que é ser, no espaço e no tempo, o agir segundo a vontade de Deus. Pontua-se, sobre o ato humano, que em esponsalidade com o Criador, possibilita a pessoa ser o ato administrativo de Deus na Criação, remete-se à relação e interação entre a oração e o coração, (co-orar+ação), e se aponta que um “coração novo, coração de carne" (Ez 36,26), é uma relação de edificação da vida humana, de cada vida humana.

O ser humano alimenta-se na esponsalidade com o Criador, é por isso uma missão dada a si mesmo, práxis de vida e vivência, segundo a pessoa que administra a obra de Deus. Quando se enfatiza o ser humano como o homo ad-minister se alimenta a racionalidade humana, todavia, em nenhum momento se deseja condicionar a esponsalidade com o Criador a este dom, a razão.

A razão propicia ao ser humano a capacidade de fazer, de realizar, de controlar, de cultivar e guardar. O Dom dos dons é o Espírito Santo, a Graça, o próprio Deus que se dá, a essência administrativa é uma resposta humana a este Espírito, é o aceitar ser "filhos/ben"”, de Deus, é luz que ilumina a práxis de vida e vivência humana, que cultiva e guarda a Criação segundo a vontade, o agir de Deus.

É afirmativa a associação e inter-relação, enquanto metodologia, entre Teologia e Administração, de modo que realizar a vontade de Deus - esponsalidade - significa administrar a criação e, por isso, há práxis teológica. E, à medida que se faz teologia, compreende-se como administrar a Criação e, neste sentido, subentende-se que "a vida que Deus oferece ao homem, é um dom, pelo qual Deus participa algo de Si mesmo à sua criatura" (João Paulo II, 1995, nº 34).

Eis que "Iahweh Deus tomou o homem e o colocou no jardim de Éden para o cultivar e o guardar" (Gn 2,15). Sendo dever do ser humano cultivar o jardim, insere-se o momento posterior, a necessidade de administrar e cocriar. Administrar e dar significado, sentido e possibilidades ao que existe, avançando sobre o que não é possibilitado, mas que se alça em ser possibilitado, no futuro, pela ação humana, mediante a essência administrativa.

O humano sempre se des-envolve mediante a essência administrativa e se torna ato administrativo de Deus na criação. Enseja-se que a esperança é constitutiva da ação necessária em perspectiva do reino esperançado. É preciso compreender que "a interpretação correta do conceito de ser humano como senhor do universo é entendê-lo no sentido de administrador responsável" (Francisco, 2015, nº 116).

\section{Metodologia}

Procura-se a elucidação de questões que estão relacionadas ao ser humano, vertendo-se a compreendê-lo como administrador da obra de Deus. Mediante os procedimentos metodológicos, conduziu-se às possibilidades, às interpretações e às informações, na afirmativa que "uma narrativa é composta por uma sequência singular de eventos, estados mentais, ocorrências envolvendo seres humanos como personagens ou autores" (Bruner, 2002, p. 46).

A narrativa tem por finalidade explorar, aprofundar e dar respostas às particularidades, onde a realidade não pode, ou não deve ser quantificada. Ainda particulariza que "uma verdadeira pesquisa narrativa é um processo dinâmico de viver e contar histórias, e reviver e recontar histórias" (Clandinin \& Conelly, 2011, p. 18)

Para explorar o universo dos significados, das aspirações, das crenças, dos valores e práxis humana foram utilizados, para a narrativa, dois núcleos fundamentais de dados, textos e informações. A saber: os documentos que constituem a Doutrina

${ }^{2}$ Francisco, 2016. $n^{\circ} 14$. 
Social da Igreja (DSI); e os documentos que elucidam o projeto, a vivência e a dinâmica familiar, segundo a Igreja Católica. O uso desses dois núcleos tem por base sua universalidade, isto é, documentos que se destinam a toda a humanidade, mediante os dons de cada pessoa.

Cada um dos itens da pesquisa foi desenvolvido tendo por base os textos/documentos apresentados. Como pontos de discernimento, foram pesquisadas fontes para dar às narrativas um sentido de diálogo, com fundamentações de teólogos que não estão inseridos nos dois núcleos apresentados.

\section{Resultados e Discussão}

Cada um dos itens da pesquisa foi desenvolvido tendo por base os textos/documentos apresentados. Como pontos de discernimento, foram pesquisadas fontes para dar às narrativas um sentido de diálogo, com fundamentações de teólogos que não estão inseridos nos dois núcleos apresentados.

\subsection{Palavra de Deus e o agir humano}

A vida humana na dinâmica de lembrar, repor, recompor e supor seu próprio passado, indaga-se quanto à própria origem, precisando olhar para o íntimo e para além de si para compreender-se "filhos/ben", em uma procura com prudência e cuidado. É a procura que alimenta o agir em humanidade. As ações são funções especificas que decorrem dos atos humanos que cocriam e administram a criação.

A pessoa tem identidade, memória, presente e expectância, onde planeja o que ser no tempo que há de vir, o futuro, "na verdade, a caridade reflete a dimensão simultaneamente pessoal e pública da fé no Deus bíblico, que é conjuntamente 'Ágape' e 'Logos': Caridade e Verdade, Amor e Palavra" (Bento XVI, 2009, nº 3). Aqui é clara a observação de que a obra de Deus é completa, embora, não conclusa. Todo o tempo/espaço é necessário e faz parte da criação que se faz pela Palavra de Deus, que continua atuante na obra, em relação de alteridade e desenvolvimento. Cada indivíduo "cristão que está atento em ouvir a Palavra de Deus vivo, unindo o trabalho à oração" e quer "saber que lugar ocupa o seu trabalho não somente no progresso terreno, mas também no desenvolvimento do Reino de Deus, para o qual todos somos chamados pela potência do Espírito Santo e pela palavra do Evangelho" (João Paulo II, 1981, n²7).

A corporeidade humana é possibilitada pela Palavra de Deus a agir na Criação. Cada pessoa tem a possibilidade de agir no espaço, em determinado tempo, espírito que edifica o coração, na co-oração. O descanso de Deus é tempo do agir humano. A Palavra de Deus habita o íntimo de cada pessoa, possibilita a essência administrativa, práxis de vida e vivência, o agir que cuida da criação de Deus cocria e a administra.

Compreende-se o amor porque se é criado por amor e no amor, e há no ser humano a potência com a qual se é amado; compreende-se o tempo, porque há a potência com a qual se age no tempo, que contingência e torna a criação necessitada de desenvolvimento. Na dinâmica do espaço que se apresenta ao próprio tempo, percebe-se que "a eternidade deste Deus é sua futuridade inconquistável, e é na palavra que o futuro está presente. Esse Deus é comunhão conosco, e é na palavra que estamos presentes um para o outro" (Jenson, 1987, p. 190).

Rejeitar a função de ser administrador e cocriador da obra de Deus é rebelar-se contra Deus. É necessário que o agir humano se torne um movimento que possibilite colaborar e desenvolver a criação; nesse sentido "a visão cristã do fim não é a de um grande silêncio, mas de uma grande liturgia, de pregação e de nossa resposta eterna (Ap 4-5)" (Jenson, 1987, p. 190).

O ser humano sustenta-se pela Graça e a Providência Divina, assim, a kénosis de Deus se torna a base original das coisas possibilitadas, dentre as quais estão a esponsalidade com o Criador e de onde decorre a essência administrativa, o Si de

${ }^{3}$ Francisco, 2016, $\mathrm{n}^{\circ} 14$ 
Deus que habita o íntimo humano, e torna cada pessoa uma continuidade livre da ação criadora. A pessoa se desenvolve sob a base da doação original por parte de Deus, é o humano que significa a Criação, e, dessa forma, o próprio agir em sociabilidade, em economicidade, e em parentalidade. O ser humano é senhor da história humana: cria, com base no passado, no presente e na expectância as possibilidades de futuro.

A pessoa humana é um ser livre, social e racional, para viver em comunhão e desenvolvimento com o próximo, com a natureza criada e com Deus, sua ação é de administrar as relações, significar as realidades e promover culturas. Cada pessoa se edifica enquanto escreve a história da humanidade, com sua própria história na humanidade, sentido em que se pontua a inteira responsabilidade que cada pessoa tem com a humanidade, povo e filhos de Deus.

Habita o íntimo humano um desejo maior e pleno, a vontade pessoal de Deus, por um ser à Sua imagem e semelhança; assim, o ser humano é chamado a cocriar e administrar da história do Reino, no caminhar para Deus e no alargamento das possibilidades. É de se pensar que a ação humana deve sempre zelar para erigir as suas relações evitando penalizar o indivíduo, mesmo porque "a pessoa que erra não deixa de ser uma pessoa, nem perde nunca a dignidade do ser humano" (João XXIII, $\left.1963, n^{\circ} 157\right)$.

O desenvolvimento do ser humano, em suas dimensões de vida e vivência, possibilita curar a práxis. O ser humano é uma realidade psicossomática, "ademais, nunca se extingue na pessoa humana a capacidade natural de abandonar o erro e abrir-se ao conhecimento da verdade" (João XXIII, 1963, nº 157). É, então, missão, dada a si mesmo, e se edifica no livrearbítrio, na obra de Deus, de tal forma que essa procura cheia de mistérios, e até sofrimentos/sacrifícios, põe a criação e o Criador à prova.

\subsection{Capacidade de ouvir a palavra de Deus}

A essência administrativa tem por base, a esponsalidade com o Criador, que desperta o humano à comunhão com toda a criação, e nesta, compreende que "Deus escreveu um livro estupendo, 'cujas letras são representadas pela multidão de criaturas presentes no universo"' (Francisco, 2015, n 85). O ser humano administra as realidades à sua volta, faz-se, então, ato administrativo de Deus na criação, e "descobrindo, em crescente progressão, 'a inexplorável riqueza de Cristo' (Ef 3,8), na criação, o trabalho humano se transforma num serviço prestado à grandeza de Deus” (João Paulo II, 2004, nº 262).

A Palavra de Deus edifica a vida humana à Sua imagem e semelhança, à medida que desenvolve em cada pessoa a capacidade de Ouvir. Nesse sentido, o Ouvir a Deus significa agir segundo as perspectivas do reino. Os "filhos/ben", desenvolvem-se mediante a essência administrativa, tudo o que promove o ser humano a ser cocriador e administrador da criação.

A fé é a realização do que se crê, "não como base na força da razão (filosofia) ou da religião (experiência), mas tãosomente pelo poder do Espírito Santo. 'Ninguém pode dizer: 'Jesus é Senhor' exceto pelo Espírito Santo' (1Co12,3)” (Braaten, 1987, p. 523). Neste sentido, "um Deus que deseja ser conhecido assim atuará dentro do ouvinte para fazer da palavra ocasionadora uma palavra possibilitadora" (Sponheim, 1987, 230), sendo a esponsalidade com o Criador a fonte de onde jorra a essência administrativa - o Si de Deus - que se torna imanente nas ações/obras humanas:

Ao ato do falar de Deus pertence também o ato do diferenciar ordenador de Deus. Deus põe ordem na sua criação, na medida em que ele diferencia entre luz e trevas, céu e terra, dia e noite. Através desta diferenciação, suas criaturas obtêm uma forma identificável, ritmo e simetria. (Moltmann, 1993, p. 123)

${ }^{4}$ Francisco, 2016, n ${ }^{\circ} 14$ 
Compreender que o humano edifica o próprio ser na esponsalidade é de fundamental importância para se edificar a vida humana sob a perspectiva da dignidade de toda e cada pessoa; "o Espírito Santo media a relação de fé com a pessoa de Cristo e gera a compreensão de que Jesus não é meramente Jesus; ele é o Cristo em quem Deus está presente e atua" (Braaten, 1987, p. 523). Sem a esponsalidade com o Criador a vida humana torna-se vazia, só restando a solidão original; tudo se resume ao nada, uma vida sem Deus, sem Criador, uma vida em que não se é amado. Nesse sentido, João XXIII ressalta que "a trágica experiência de gigantescas forças, que, postas ao serviço da técnica, tanto podem utilizar-se para construir como para destruir, põe em evidência a importância suprema dos valores do espírito" (João XXIII, 1961, no 209). E, ressalta o pontífice, tal experiência "mostra que o progresso científico e técnico há de conservar o seu caráter essencial de meio para a civilização" (João XXIII, 1961, nº 209).

Ser à imagem e semelhança de Deus possibilita administrar e cocriar à criação. Portanto, o livre-arbítrio é percebido em seu princípio de divindade, de liberdade e sociabilidade, de comunhão e de responsabilidade. Com isso, é possível afirmar que “o 'dominar' está atrelado àquela correspondência dos seres humanos a Deus, o criador e mantenedor do mundo, que é denominada de 'à semelhança de Deus"' (Moltmann, 1993, p. 54). Assim, ousa-se observar a palavra 'mantenedor' e substituíla e/ou compará-la por administrador.

Ainda sobre os conceitos de dominar, é possível enfatizar a atitude de conhecer plenamente a criação, para que assim o ser humano possa agir de forma prudente e responsável, na práxis da essência administrativa. É o esforço para manter a morada que empreende o humano, tendo em si a essência administrativa que o possibilita significar, submeter, "cultivar e guardar O Jardim", enquanto cumpre a missão de "ir e proliferar" (Gn 1, 28).

O Reino, uma vez na história, ou ainda, a história de cada pessoa, uma vez no Reino, também é novidade para Deus, porque no Reino há espaço para a livre e espontânea participação dos seres humanos. A práxis humana no Reino é o start necessário de toda ação, todo esforço que alguém faz/realiza pode trazer uma nova realidade, que possibilita viver melhor a contingência da vida humana, no Reino em desenvolvimento. Sempre haverá algo que acaba e algo que permanece: a dedicação da mãe, a relação entre pai e filho, a alegria do novo conhecimento, a dignidade de se ter uma casa, e assim se desenvolvem as culturas e sua relação com o Criador, porque "para todos os seres humanos constitui quase um dever pensar que o que já se tiver realizado é sempre pouco, em comparação do que resta por fazer" (João XXIII, 1963, nº 155).

Diante desses elementos enfatiza-se que cada atitude de formação da consciência de pessoa gera processos de amadurecimentos. É a essência administrativa e sua práxis que possibilitam ao Reino o desenvolvimento. Assim permanecem todas as coisas que foram feitas a partir daquilo que o Reino foi, é, e sempre será. Porque tudo o que se constrói em atitudes de amor, esponsalidade se torna uma nova realidade permanente e eterna do Reino.

\subsection{Administrar: práxis à racionalidade humana}

Há de se apresentar à racionalidade humana e a sua práxis um entendimento do que é o ser humano e seu agir para administrar e cocriar o Reino de Deus. É válido lembrar que Jesus não ensina o ser humano a ser Deus, mas a ser criatura ungida na criação, que edifica o Reino, segundo a vontade do Criador. Bento XVI reforça que "por isso, para a prossecução do desenvolvimento, servem 'pensadores capazes de reflexão profunda, em busca de um humanismo novo, que permita ao homem moderno o encontro de si mesmo"” (Bento XVI, 2009, n 19).

O encontro de si mesmo evidencia a necessidade de aprender, de ensinar e de se envolver com as dimensões da própria vida humana. É o amor que eleva a pessoa à nação dos filhos de Deus, onde se desenvolvem os dons de cada pessoa com base nas dimensões de economicidade, de sociabilidade e de parentalidade.

A potência humana não pode dar vida às obras de seus atos, "como $o b r a$, a criação não é similar ao criador em sua essência, mas é expressão da sua vontade” (Moltmann, 1993, p. 124), por isso, é função humana administrar a criação. O Si de 
Deus que habita o íntimo humano, possibilita a esponsalidade, relação com o Criador, e dela a essência administrativa, Graça necessária para ser à imagem e semelhança de Deus, no livre-arbítrio e na contingência do Reino em desenvolvimento.

O esforço teológico e administrativo necessário para responder sobre a vida e vivência humana está ao movimento da potencialidade humana. Essa que é necessária para compreender que há no humano um Si de Deus, por isso "como imagem, as pessoas correspondem a Deus em sua essência, porque Deus se corresponde a si mesmo em suas criaturas" (Moltmann, 1993, p. 124).

Nesse sentido, referenda-se que "o humanum primordial que surge da criação de Deus é constituído pelo chamado (destino) e pela capacidade de participar como co-criador ordenado do ímpeto criativo de Deus" (Hefner, 1987, p. 328). Sobre esse preceito é possível "ousar um pouco e afirmar que Deus está passando cada vez mais a responsabilidade para os humanos, no sentido de envolvê-los cada vez mais em seu plano" (Sanches, 2007, p. 155).

O ser humano revelado em Cristo é destino, uma finalidade que supera a si mesmo, por ser concebido à imagem e semelhança de Deus. Portanto, sua natureza é a de um ser que é em esponsalidade como Criador, porque "é constituído pelo chamado" (Hefner, 1987, p. 328), e neste chamado é o ato administrativo de Deus na Criação.

Ser natureza humana é ser chamado - por dom de Deus - a participar da natureza Divina, não como um novo deus, mas como criaturas ungidas que, de forma livre, consciente e responsável, fazem segundo a vontade do Criador. Como adverte Moltmann: "nessa relação de Deus para com as pessoas existe, no entanto, também a relação da pessoa para com Deus, sua existência reflexiva e responsória que está em sua natureza de imagem" (Moltmann, 1993, p. 335). De modo que "a coisa importante a ser dita sobre o ser humano, a partir de uma perspectiva cristã, é que ele é criado com um destino cujo desdobramento contém a aventura humana" (Hefner, 1987, p. 324). Consequentemente, "esta compreensão precisa agora ser moldada em novos termos para comunicar a fé cristã adequadamente" (Hefner, 1987, p. 324).

Hefner faz uma opção pelo termo: “'co-criador criado' para articular o que significa a humanidade sob a vontade de Deus. Este termo fala de dependência, de poder e autoridade dados por Deus e de liberdade dentro da finitude" (Hefner, 1987, p. 324). Quando se enfatiza o ser humano enquanto cocriador e administrador do Reino, apresenta-se que as potencialidades "estão em continuidade, dentro do esquema evolutivo, com formas prévias de vida, mas ao mesmo tempo são única sem sua configuração precisa e altamente sofisticada na espécie humana" (Hefner, 1987, p. 328.). Evidencia-se que o ser humano é o administrador e cocriador da obra de Deus, sugerindo "que este caráter de co-criador (sic) é o que significa ser 'à imagem de Deus"” (Hefner, 1987, p. 328.).

Diante do avanço "da ciência e os inventos da técnica demonstram, antes de tudo, a infinita grandeza de Deus, criador do universo e do homem" (João XXIII, 1963, nº 3) e referindo-se ao Deus Criador, é enfático que "foi Ele quem tirou do nada o universo, infundindo-lhe os tesouros de sua sabedoria e bondade" (João XXIII, 1963, n 3). Observa-se o conceito de esponsalidade na família humana com Deus, ou seja, a unidade que existe em todos os que se direcionam ao Ser.

Foi igualmente Deus quem criou seres humanos à sua imagem e semelhança (Gn 1,26), dotado de inteligência e liberdade. E o constituiu senhor do universo, como exclama ainda o Salmista: 'Tu o fizeste pouco menos do que um deus, coroando-o de glória e beleza. Para que domine as obras de tuas mãos sob seus pés tudo colocaste” (S1 8,5-6).

A parentalidade que se origina na biologicidade deve guiar-se à genealogia de Deus, refletir-se-á, então, o amor à sociabilidade, movimentando-se ao bom, ao belo e ao verdadeiro, onde se edifica o Reino. A parentalidade é fonte de onde jorra o amor à criação de Deus e, nesse sentido, compete a cada pessoa e em especial, ao pai e à mãe o amor, e o ensinar a amar. O amor torna-se a fonte de racionalidade de cada pessoa, aprende-se a pensar em um universo de possibilidades amorosas. 


\subsection{O ser humano e a palavra de Deus}

O humano que é arbitrado a viver, em livre-arbítrio, na esponsalidade com Deus, é capaz de administrar a criação, segundo as possibilidades de proporcionar espaço e luz a toda criatura, porque "Deus é amor: aquele que permanece no amor permanece em Deus e Deus permanece nele" (1Jo 4,16). Sob esta perspectiva, pontua-se a solidão original, a pessoa quando intenta a ser causa de si mesmo termina por sentir o vazio de uma vida sem Criador, não se sustentando como ser não amado.

Habita o íntimo humano o Si de Deus e possibilita que a vida humana, preenchida pelo Espírito Criador, se torne ato administrativo da vontade Divina. A esponsalidade possibilita ao ser humano o diálogo com Deus, com o próximo, e com a própria natureza criada. Somos ouvidos atentos às manifestações das necessidades de amor e, com essas informações, pode-se afirmar que o agir humano deve ser percebido enquanto ato administrativo e cocriador de Deus; o ser humano é sinal da presença de Deus.

Na ausência de esponsalidade, o ser humano força a construção de um mundo sem Deus, um paraíso terrestre que dá continuidade à construção da "torre de Babel” (Gn 11,1-9). Quando o ser humano se nega ao amor à esperança, coloca-se a negar o Criador e "se deixa seduzir pela serpente e deita a mão à árvore da vida caindo em poder da morte" (João Paulo II, 2004, n 115).

O humano, que na solidão original, postula-se como senhor de si mesmo, causa de si mesmo, justifica-se enquanto um ser absoluto, soberbo e avarento. Isto é, “com esse gesto o homem tenta forçar o seu limite de criatura, desafiando Deus, único Senhor do homem e fonte da vida. Um pecado de desobediência (cf. $R m$ 5,19), que separa o homem de Deus" (João Paulo II, 2004, $\mathrm{n}^{\text {o }}$ 115). Na contingência da Criação, a árvore da vida está na atitude de esponsalidade com o Criador, no caminhar em livre-arbítrio, sendo o cocriador e administrador da obra a qual é sua fonte de vida, ainda que se saiba que, "os bens, quais a dignidade do homem, a fraternidade e a liberdade, todos os bons frutos da natureza e da nossa operosidade, [...], pertencem ao Reino [...] que Cristo entregará ao Pai e lá os encontraremos novamente” (João Paulo II, 2004, n 57).

O próprio Gênesis diz muito sobre o que o ser humano deve fazer em função do que é. As coisas e animais foram criados, como resultado do Verbo/Palavra de Deus. O ser humano é diá-logos, Palavra de Deus. Quando Deus diz “façamos o humano à nossa imagem, como nossa semelhança" (Gn 1,26), "Ele falou, na Trindade, com o Filho que deveria assumir o homem, e com o Espírito, que deveria santificar o homem, como ministros e membros do conselho" (Jenson, 1987, p. 139.).

Templo do Espírito Santo, o ser humano é um ad-minister da Palavra. Sua práxis, efetivamente, realiza o ato administrativo de Deus na Criação, portanto, a Essência administrativa - o Si de Deus, desperta a pessoa no mandado e no chamado de cocriar e administrar a criação de Deus. Tem-se, então, o húmus da terra, o homo ad-minister. Deus não cessa de amar a sua Criação, bem como possibilita à vida humana ser templo do Espírito Santo e, com isso, Deus faz sua morada na criação, "nesta relação de Deus com sua imagem na terra, já podemos reconhecer uma relação mais íntima do que aquela que existe na contraposição do criador à obra de sua criação [...]” (Moltmann, 1993, p. 124).

É possível compreender que, diante dos seis dias da criação, houve uma gradualidade; o ser humano, todavia, não é uma sucessão natural, há em Deus, um diálogo amoroso e relacional. Deus que é Criador ex-nihilo, é também Deus que governa, administra e cocria a partir do que há e nesse sentido, chama à existência, o ser humano, propulsando o Cristo à vida, ao dizer "façamos o humano à nossa imagem, como nossa semelhança, e que eles dominem" (Gn 1,26).

O ser humano é palavra de Deus se pronunciando, o humano é o dominus - o senhor da casa. Sob tal preceito pontuase a diferença entre o Criar de Deus e o Agir de Deus, "é errado transferir as formas do criar divino no início para as formas do agir divino na história” (Moltmann, 1993, p. 285), ser à imagem e semelhança de Deus, é também o agir histórico, na edificação do Reino. Para Hefner "quando os seres humanos ponderam seu status de co-criadores, reconhecem que ele inclui a liberdade de conceber ações e executá-las" (Hefner, 1987, p. 328). Tal liberdade, afirma o autor, é "aprazível, até deliciosa; 
sustenta a agressividade humana como homo faber (ser humano como operário ou artífice), inclusive até os resultados tecnológicos de larga escala que estão agora à nossa volta” (Hefner, 1987, p. 328).

Deus cria, ao possibilitar o nada/ex-nihilo ser e, posteriormente, administra e cocria, a partir do que há. Primeiro fala ao nada/ex-nihilo e desse ao caos, é uma Palavra que se impõe e propõe a criação. Ao fim do quinto dia, vendo tudo o que fez em alteridade e desenvolvimento com o já criado, no diálogo circumincetivo de $\mathrm{Si}$, e no desejo por um correspondente, que possa cocriar e administrar a Criação, diz, no sexto dia, "façamos o humano à Nossa semelhança como Nossa imagem" (Gn 1,26) e da origem no húmus da terra, o homo ad-minister.

Não se esquece aqui, que Cristo é anterior ao ato, por isso desde o diálogo circumincetivo para com o nada/ex-nihilo há a presença do Cristo e do Espírito Santo, portanto nele há a imagem e semelhança, para o qual e com o qual tudo foi criado. O humano é desejado por Deus, é a Palavra do próprio Deus que, em diálogo com sua própria obra, diz "Façamos o humano" (Gn 1,26). Aqui existe a edificação da corporeidade humana, em dignidade da pessoa, à imagem e semelhança do Criador, que precisa se desenvolver.

Quando pensado sob gênesis, a concepção da vida humana é realizada no diálogo íntimo de Deus, é a palavra de Deus que se faz Carne, vida humana. A dignidade da pessoa se faz no desejo de Deus, por um correspondente, e que administrando o que há, faz emergir do húmus da Criação, o humano.

\subsection{Início de uma vida humana eterna}

A dignidade humana não está em afirmar sua superioridade em relação às outras criaturas, mas fundamenta-se em ser à imagem e semelhança de Deus, portanto, aquele que deve administrar e cocriar a obra de Deus. A entrega de si ao serviço e cuidado amoroso da criação possibilita que o ser humano, ao mesmo tempo em que reconhece as criaturas e com isso dá significado à criação, faz com que o próprio agir seja glorificado ao ser o ato administrativo de Deus. Dessa forma, o ato humano é cocriador, é relação, é Amor, é Liberdade e Redenção. Em sentido amplo, ser à imagem e semelhança de Deus é exercer a capacidade de amar.

A essência administrativa decorre da ação de Deus ao chamado/mandado da vida humana, em um processo de alteridade e esponsalidade entre o Criador e a vida humana. Quando se enfatiza que a razão, por si mesma, não torna a pessoa semelhante ao Criador, afasta-se do gnosticismo e, ao mesmo tempo, procura-se com isso o que menciona Bento XVI ao afirmar que "só através da caridade, iluminada pela luz da razão e da fé, é possível alcançar objetivos de desenvolvimento dotados de uma valência mais humana e humanizadora" (Bento XVI, 2009, nº 9.).

A educação de cada ser humano concebido se faz em processo de alteridade e desenvolvimento; isso implica dizer que a criança/pessoa é um ser que se alimenta da cultura de seu povo, para depois dar continuidade à vida e à vivência. Formar a consciência de cada pessoa é possibilitar a ela que dê nome e significado à criação e, com isso, é possível compreender que,

a partilha dos bens e recursos, da qual deriva o autêntico desenvolvimento, não é assegurada pelo simples progresso técnico e por meras relações de conveniência, mas pelo potencial de amor que vence o mal com o bem (cf. $R m$ 12, 21) e abre à reciprocidade das consciências e das liberdades. (Bento XVI, 2009, nº 9)

A essência administrativa não é reduzida à razão, mas assume todo o significado da experiência humana em esponsalidade. A noção de práxis humana engloba, claramente, a dimensão de economicidade, de sociabilidade, e de parentalidade, sob diversos contextos, fundamentando a vida, a vivência, e a missão de cada pessoa.

Administrar e cocriar as relações humanas é mistério, responsabilidade, e se faz no enigma de estar em esponsalidade, "a existência moral é resposta à iniciativa amorosa do Senhor. É reconhecimento, homenagem a Deus e culto de ação de graças. É cooperação com o plano que Deus executa na história” (João Paulo II, 2004, no 22) história que se faz em passado, 
presente, expectância e futuro. Tais dimensões da vida, memória humana, precisam ser analisadas constantemente, para aprender como se proceder enquanto sociabilidade, parentalidadee economicidade com a obra de Deus. Assim, reflete Moltamnn, "a memória não pega de volta o passado, mas somente o representa através de impressões e imagens" de tal modo que "a expectativa não antecipa o próprio futuro, mas antecipa experiências e ações futuras através de imagens e concepções insuficientes" (Moltmann, 1993, p. 176).

Prefigura-se o Reino, e isso se faz porque "a memória apresenta uma certa recriação de coisas passadas no presente. Também a expectativa apresenta uma certa nova-criação do futuro no espírito presente” (Moltmann, 1993, p. 176). É esta a base sobre a qual se administra e se cocria o Reino de Deus, que já se faz presente, só que ainda não em sua plenitude, João Paulo II enfatiza que:

A experiência dos anos mais recentes demonstra, pelo contrário, que se toda a massa dos recursos e das potencialidades, postos à disposição do homem, não for regida por uma intenção moral e por uma orientação no sentido do verdadeiro bem do gênero humano, ela volta-se facilmente contra ele para o oprimir. (João Paulo II, 1987, $\left.\mathrm{n}^{\circ} 28\right)$

Cada criança concebida deve ser alimentada na esperança de comunhão de seu povo, e que essa comunhão nunca deve se cessar no próprio povo. Desenvolver um povo é desenvolver cultura, de modo que, seus constituintes se tornem capazes de reconhecer o próximo e outras culturas, como carne da mesma carne, e ossos dos mesmos ossos. Movimenta-se no sentido de edificar a nação dos filhos de Deus, uma nação sem limites geográficos, uma nação que se mensura pelo sentir-se amado por Deus, e por amar ao próximo como Deus ama a cada pessoa.

O fato é que, "quando da união conjugal dos dois nasce um novo homem, esse traz consigo ao mundo uma particular imagem e semelhança do próprio Deus: na biologia da geração está inscrita a genealogia da pessoa" (João Paulo II, 1995, nº 43). Cada célula que possibilita a continuidade biológica do ser humano é regrada por valores e princípios, e é exponenciada na esponsalidade com o Criador.

\subsection{Expectação e futuro}

Em se tratando de culturas, é possível afirmar que quando só se valoriza o presente, corrompe-se o futuro; quando só se valoriza o passado, despreza-se o presente e se rompe com a linha do tempo, quando só o futuro se abstrai da realidade no tempo. A referida abstração não é um efeito capaz de se planejar, mas uma fuga da realidade, para viver no mundo das ideias e ideais, as aterrorizadoras ideologias, que liquefazem a liberdade, sob o preceito da construção do paraíso terrestre.

Sob essa perspectiva devem ser considerados assuntos da Teologia, fomentando que a hodiernidade, quando na perspectiva do Reino de Deus, constitui-se de cronologia e de escatologia, assim a memória humana edifica a história: passado, presente, expectância e futuro. A esperança é constitutiva da ação necessária para a realização do Reino, isso dá brilho à vida humana, como senhor da história, em uma economicidade de desenvolvimento e salvação.

Nesse sentido, o ser humano procura "com seu trabalho e engenho, desenvolver mais a própria vida; hoje, porém, sobretudo graças à ciência e à técnica, estendeu o seu domínio à natureza inteira, e continuamente o aumenta" (Paulo VI, 1965, $\mathrm{n}^{\mathrm{o}}$ 33). A esponsalidade com o Criador, realizada nas obras de cada pessoa, é um projeto de amor e doação, e ainda que haja indagações "muitas são as questões que se levantam entre os homens, perante este imenso empreendimento, que já atingiu o inteiro gênero humano" (Paulo VI, 1965, nº 33).

O arbítrio da concepção, e no livre-arbítrio da interdependência da criação, se edifica o húmus da Criação, para ser o administrador e cocriador, "isto se torna evidente já pelo fato de a resolução de Deus para Cristo e sua obra de salvação sustenta essa própria obra salvífica, e não é sustentada por ela". Ainda mais, "que não é a ação de Cristo que realiza a vontade 
de remissão de Deus, mas é efetuada por ela; que essa redenção em Cristo [...] era já presente desde o começo da humanidade" (Rahner, 1969, p. 126-127).

E, nesse sentido "a família humana, sobretudo devido ao aumento de múltiplos meios de comunicação entre as nações, vai-se descobrindo e organizando, progressivamente, como uma só comunidade espalhada pelo mundo inteiro" (Paulo VI, 1965, n 33) - é a nação dos filhos de Deus, nação onde não há fronteiras, porque é regida pelo amor.

A pessoa é dignificada mediante a concepção à imagem e semelhança de Deus, ou seja, uma relação de amor para consigo mesma, para com o Criador e para com a criação, relação essa que possibilita o livre-arbítrio. E, com isso, é evidente "que a salvação do homem não depende somente da ideia, mas da contingência concreta da história real" (Rahner, 1969, p. 128). A essência administrativa habita o íntimo humano, é constitutiva da corporeidade humana, e propicia capacidade de compreender, de tornar-se sujeito diante de tudo o que lhe faz perceber enquanto ambiente de convívio. Essa percepção é o elemento da essência administrativa, que mantém o humano em correspondência e esponsalidade à perspectiva do reino de Deus, onde o ser humano "é chamado a uma plenitude de vida que se estende muito para além das dimensões da sua existência terrena, porque consiste na participação da própria vida de Deus" (João Paulo II, 1995, n 2). Nota-se que o humano e suas dimensões de sociabilidade, de economicidade, e de parentalidade estão em função da perspectiva do Reino de Deus, subsidiada na esponsalidade.

Eis que a dinâmica socioeconômica em esponsalidade com o Criador deve constituir um conjunto a ser analisado nas propostas de planejamento da parentalidade. A vida eterna se torna perene para o ser humano, na contingência do reino em desenvolvimento; é o amor, que possibilita ao humano ser o húmus da terra, renovar-se constantemente, alimentando o eterno, "é o olhar de quem não pretende apoderar-se da realidade, mas a acolhe com um dom, descobrindo em todas as coisas o reflexo do Criador e em cada pessoa a sua imagem viva (Gn 1,27; Sal 8,6)" (João Paulo II, 1995, nº 83).

A essência administrativa possibilita a dinâmica, que transforma e cocria a criação sobre uma base da doação original das criadas por Deus. Quando se fala da concepção humana, enfatiza-se que o casal é capaz de doar-se e neste doar da pessoa, Deus é o primeiro a sustentar o amor e a vida eterna. A cocriação acontece em uma condição de contingência, na qual o humano, com firme olhar, avança entre angústias e esperanças buscando possibilitar uma criação cada vez mais digna para a pessoa.

É diante da técnica extremamente apurada, da tecnologia amplamente desenvolvida, que ainda se veem pessoas passando fome, sem nenhuma instrução que lhes possibilite participar do mundo que o ser humano desenvolve. Diante desses elementos e na observação do trabalho humano, indaga: "Qual o sentido e valor desta atividade? Como se devem usar estes bens? Para que fim tendem os esforços dos indivíduos e das sociedades?" (Paulo VI, 1965, nº 33.).

Nesse sentido, a esponsalidade com o Criador faz-se necessária porque o humano "separado de Deus, torna-se desumano consigo mesmo e com os seus semelhantes, porque as relações bem ordenadas [...] pressupõem relações bem ordenadas da consciência pessoal com Deus" (João XXIII, 1961, n 214). A relação do ser humano com Deus sugere que se tenha um ordenamento para agir segundo a Sua vontade. Conhecê-Lo, portanto, situa-se no âmbito de dar continuidade, práxis, a vontade de Deus.

Se o ser humano desenvolveu seu sentido de negócios, é necessário desenvolver-se em esponsalidade com o Criador, retomar o seu caminho de filhos de Deus, de administradores e cocriadores do Reino. Prospectar o futuro é permitir ao ser humano ser o administrador e cocriador da Criação, em esponsalidade com o Criador.

\section{Conclusão}

O entendimento do agir humano movimenta cada pessoa a ser um sinal da presença de Deus na Criação, de modo que se possa ver/sentir Deus conosco. É necessário superar a dicotomia, agir humano - agir de Deus, e prover a consciência da 
pessoa para que viva em esponsalidade com o Criador. É urgente reavivar nos cristãos a boa nova da visão de mundo em que a ação humana é simultaneamente ação divina na construção do Reino.

Dizer da co-oração que o ser humano é capaz de realizar com Deus é reconhecer que essência administrativa propulsa a capacidade de compreender o passado, o presente, a expectação e realizar o futuro, não enquanto domínio absoluto, do tempo e do espaço, mas enquanto doação de si a serviço de outrem, da criação, de Deus e, com isso, de si mesmo. Tal essência possibilita ouvir a Palavra, sentir o agir da Palavra e no chamado/mandado de Deus.

O ser humano é a criatura ungida que cultiva e guarda o Jardim, administrando os mistérios de Deus que se apresentam na Graça, na Essência Administrativa e na Providência Divina. Assim o agir humano é a dinâmica temporal no Reino. Dizer da esponsalidade com o Criador é realizar uma co-oração, que alimenta o "novo coração" (Ez, 36,26), é reconhecer que "no fundo é o próprio Deus que oferece [...] a honra de cooperar com todas as forças da inteligência na obra da criação" (João Paulo II, 2004, n 460).

A racionalidade é humana, não necessita da esponsalidade com o Criador. Deus criou o ser humano racional, todavia, a essência administrativa é dependente de esponsalidade, por isso o ser humano é, mediante a essência administrativa, uma resposta concreta ao chamado/mandado de Deus. A essência administrativa é práxis, e movimenta o ser humano à esperança, à vida eterna.

A concepção é o início de vida eterna, e com isso o casal humano diz com Deus: "façamos o humano à nossa imagem e à nossa semelhança". Cuidar de filhos/as e da criação, na esponsalidade com o Criador, é possibilitar e expectar o futuro realizando uma co-oração em direção à unidade de amor e esperança onde "Deus será tudo em todos" $(1$ Cor 15,28$)$ para que todos/as sejam um.

\section{Referências}

Bento XVI. Caritas in veritate. Libreria Editrice Vaticana, 2009. http://w2.vatican.va/content/benedictxvi/pt/encyclicals/documents/hf_benxvi_enc_20090629_caritas-in-veritate.html.

Braaten, C. E. A pessoa de Jesus Cristo. In: Braaten, Carl E., Jenson, Robert W. (Eds.). Dogmática cristã. São Leopoldo: Sinodal, 1987. p. 455-551.

Bruner, J. Atos de significação. (2a. ed.) Trad. Sandra Costa: Artmed, 2002.

Clandinin, D. J., \& Conelly, F. Michael. Pesquisa narrativa: experiências e história na pesquisa qualitativa. Trad. Grupo de Pesquisa Narrativa e Educação de Professores ILEEL/UFU. Uberlândia: EDUFU, 2011.

Ezequiel. In: BÍBLIA de Jerusalém Nova edição revisada e ampliada: Paulus, 2012.

Francisco. Amoris laetitia. Libreria Editrice Vaticana, 2016. http://w2.vatican.va/content/francesco/pt/apost_exhortations/documents/papafrancesco_esortazione-ap_20160319_amoris-laetitia.html.

Francisco. Laudato si'. Libreria Editrice Vaticana, 2015. http://w2.vatican.va/content/francesco/pt/encyclicals/documents/papafrancesco_20150524_enciclica-laudato-si.html.

Gênesis. In: BÍBLIA de Jerusalém. Nova edição revisada e ampliada: Paulus, 2012.

Hefner, P. J. A criação. In: Braaten, C. E., Jenson, R. W. (Eds.). Dogmática cristã. São Leopoldo: Sinodal, 1987. p. $273-358$.

I Coríntios. In: Bíblia de Jerusalém. Nova edição revisada e ampliada: Paulus, 2012.

Jenson, R. W. O deus triúno. In: Braaten, C. E., Jenson, R. W. (Eds.). Dogmática cristã. São Leopoldo: Sinodal, 1987. p. 95-202.

João Paulo II. Laborens exercens. Libreria Editrice Vaticana, 1981. http://w2.vatican.va/content/john-paul-ii/pt/encyclicals/documents/hf_jpii_enc_14091981_laborem-exercens.html.

João Paulo II. Sollicitudo rei socialis. Libreria Editrice Vaticana, 1987. http://w2.vatican.va/content/john-paul-ii/pt/encyclicals/documents/hf_jpii_enc_30121987_sollicitudo-rei-socialis.html.

João Paulo II. Evangelium vitae. Libreria Editrice Vaticana, 1995. http://w2.vatican.va/content/paul-vi/pt/encyclicals/documents/hf_pvi_enc_25071968_humanae-vitae.html.

João Paulo II. Compêndio da doutrina social da igreja. Libreria Editrice Vaticana, 2004 http://www.vatican.va/roman_curia/pontifical_councils/justpeace/documents/rc_pc_justpeace_doc_20060526_compendio-dott-soc_po.html. 
Research, Society and Development, v. 10, n. 15, e538101523420, 2021

(CC BY 4.0) | ISSN 2525-3409 | DOI: http://dx.doi.org/10.33448/rsd-v10i15.23420

João XXIII. Mater et magistra. Libreria Editrice Vaticana, 1961. http://w2.vatican.va/content/john-xxiii/pt/encyclicals/documents/hf jxxiii_enc_15051961_mater.html..

João XXIII. Pacem in terris. Libreria Editrice Vaticana, 1963. http://w2.vatican.va/content/john-xxiii/pt/encyclicals/documents/hf_jxxiii_enc_11041963_pacem.html.

João. In: BÍBLIA de Jerusalém. Nova edição revisada e ampliada: Paulus, 2012.

Lovo, O. A. Alteridade humana e contingência no Reino. Revista Caminhando 25(3), 21-36, set./dez. 2020. https://doi.org/10.15603/2176$3828 /$ caminhando.v25n3p21-36

Moltmann, J. Deus na criação: doutrina ecológica da criação. Trad. Haroldo Reimer, Ivoni Richter Reimer. Petrópolis: Vozes, 1993.

Paulo VI. Gaudium et spes. Libreria Editrice Vaticana, 1965. http://www.vatican.va/archive/hist_councils/ii_vatican_council/documents/vatii_const_19651207_gaudium-et-spes_po.html.

Rahner, K. Teologia e antropologia: Edições Paulinas, 1969.

Sanches, M. A. Brincando de deus(!) (?): bioética e as marcas sociais da genética: Ave Maria, 2007.

Sponheim, P. R. O conhecimento de deus. In: Braaten, C. E., \& Jenson, R. W. (Eds.). Dogmática cristã. São Leopoldo: Sinodal, 1987. p. $203-272$. 